\title{
SUPPRESSION OF NASAL, SKIN, AND AERIAL STAPHYLOCOCCI BY NASAL APPLICATION OF METHICILLIN *
}

\author{
By DONALD T. VARGA AND ARTHUR WHITE $\dagger$ \\ (From the Department of Medicine, University of Louisville, Louisville, Ky.)
}

(Submitted for publication June 12, 1961 ; accepted August 17, 1961)

Untreated heavy nasal carriers of staphylococci have been reported to have staphylococci on their skin more frequently and to disseminate staphylococci in the air in larger numbers than either noncarriers or carriers of smaller numbers of these bacteria (1). If the nose is the main source of skin and aerial staphylococci, suppression of nasal staphylococci should be followed by a reduction in both aerial dissemination and skin carriage.

Of the presently available systemically administered antibiotics, only methicillin (dimethoxyphenyl penicillin) has been reported to eradicate staphylococci from nasal carriers without overt staphylococcal infections at other sites in hospitals where a large proportion of these organisms is multiple-drug-resistant (2-6). However, other investigators have reported that nasal staphylococci are eradicated less frequently and less rapidly from patients receiving methicillin for staphylococcal infections at other sites (7-9).

In the present study nasal treatment with methicillin not only suppressed nasal staphylococci but also decreased aerial dissemination of these organisms and markedly reduced skin carriage of staphylococci. Both before and after treatment, the frequency of positive skin cultures and aerial dissemination of staphylococci was proportional to the number of nasal staphylococci isolated at the time cultures were obtained.

\section{METHODS}

Quantitative nasal cultures (10) were obtained 4 or 5 times per week, January through May, 1961, from

\footnotetext{
* This investigation was supported by a research grant (E-2561) from the National Institute of Allergy and Infectious Diseases, Bethesda, Md., and by a grant from Bristol Laboratories, Syracuse, N. Y. A portion of this work was published in abstract form in Clin. Res. 1961, 9, 174.

$\dagger$ John and Mary R. Markle Scholar in Medical Sciences.
}

patients without staphylococcal infections on the wards of Louisville General Hospital for whom prolonged hospitalization was indicated. Patients were classified as nasal carriers if at least 2 of 3 pretreatment cultures contained coagulase-positive staphylococci. Patients who were nasal carriers were treated by random selection with one of four ointments ${ }^{1}$ containing $0,10,50$ or 100 $\mathrm{mg}$ of methicillin per $\mathrm{g}$ of petrolatum and lanolin ointment. A small amount of ointment was applied with the patients' fingers completely around the anterior nares 3 times per day for 1 to 2 weeks. Patients did not receive any other antimicrobial agent during this study. Skin cultures of forearm (1) and air samples using slit samplers (11) were obtained before therapy and at weekly intervals during and after therapy.

Cultures were obtained from all patients throughout their hospitalization. In patients who had not reacquired nasal staphylococci when discharged from the hospital, attempts were made to continue cultures either until staphylococci were again isolated or until at least a total of 30 days after therapy.

Cultures from patients who did not reacquire nasal staphylococci during the study were obtained in the hospital for a mean period of 23 days after treatment, with a median value of 25 days; after discharge from the hospital, additional cultures were obtained for an average period of 17 days, with a median period of 14 days.

Ten of the 14 patients who became nasal carriers after treatment did so during their hospitalization. The remaining 4 patients were followed for $10,13,17$ and 20 days after treatment in the hospital, during which time their nasal cultures remained negative, and for an additional 33, 14, 41 and 38 days, respectively, after discharge before staphylococci were isolated.

A coagulase-positive staphylococcus from each positive culture was phage typed ${ }^{2}$ and its susceptibility to penicillin G, tetracycline, erythromycin, chloramphenicol, kanamycin and methicillin was determined by plate-dilution methods (12). Staphylococci requiring $10 \mu \mathrm{g}$ or more for inhibition were considered resistant. By these standards, none of the staphylococci was resistant to methicillin or kanamycin.

${ }^{1}$ Ointments with and without dimethoxyphenyl penicillin were obtained from Dr. E. M. E. Morigi, Bristol Laboratories, Syracuse, N. Y.

2 Staphylococcal bacteriophages and propagating strains were supplied by Dr. John Blair, Hospital for Joint Diseases, New York, N. Y. 
TABLE I

Comparison of number of staphylococci isolated before treatment from patients who remained noncarriers as compared with patients who reacquired staphylococci

\begin{tabular}{|c|c|c|c|c|}
\hline \multirow[b]{2}{*}{$\begin{array}{l}\text { No. of } \\
\text { staph. }\end{array}$} & \multicolumn{2}{|c|}{ Noncarriers } & \multicolumn{2}{|c|}{ Reacquired } \\
\hline & $\begin{array}{l}\text { No. of } \\
\text { cultures }\end{array}$ & $\begin{array}{l}\text { Per cent } \\
\text { cultures }\end{array}$ & $\begin{array}{c}\text { No. of } \\
\text { cultures }\end{array}$ & $\begin{array}{l}\text { Per cent } \\
\text { cultures }\end{array}$ \\
\hline 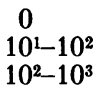 & $\begin{array}{l}3 \\
3 \\
4\end{array}$ & $\left.\begin{array}{l}13 \\
13 \\
17\end{array}\right\} 43$ & $\begin{array}{l}3 \\
4 \\
6\end{array}$ & $\left.\begin{array}{r}6 \\
8 \\
12\end{array}\right\} 26$ \\
\hline $\begin{array}{l}10^{3}-10^{4} \\
10^{4}-10^{5}\end{array}$ & $\begin{array}{l}3 \\
5\end{array}$ & $\left.\begin{array}{l}13 \\
22\end{array}\right\} 35$ & $\begin{array}{r}12 \\
1\end{array}$ & $\left.\begin{array}{r}25 \\
2\end{array}\right\} 27$ \\
\hline $\begin{array}{l}10^{5}-10^{6} \\
>10^{6}\end{array}$ & 2 & $\left.\begin{array}{r}9 \\
13\end{array}\right\} 22$ & $\begin{array}{l}12 \\
10\end{array}$ & $\left.\begin{array}{l}25 \\
21\end{array}\right\} 46$ \\
\hline & 23 & 100 & 48 & 100 \\
\hline
\end{tabular}

RESULTS

No differences were seen in the results obtained with the three concentrations of methicillin. All patients treated with ointments containing methicillin became noncarriers during treatment, but

TABLE II

Nasal carrier rates for coagulase-positive staphylococci in patients treated with topical methicillin

\begin{tabular}{|c|c|c|c|c|c|}
\hline \multirow{2}{*}{\multicolumn{2}{|c|}{ Treatment day }} & \multicolumn{2}{|c|}{$\begin{array}{c}\text { Treated } \\
\text { patients } \\
(22 \text { cases })\end{array}$} & \multicolumn{2}{|c|}{$\begin{array}{l}\text { Placebo } \\
\text { patients } \\
(7 \text { cases) }\end{array}$} \\
\hline & & $\begin{array}{c}\text { No. } \\
\text { cultured }\end{array}$ & Positive & $\begin{array}{c}\text { No. } \\
\text { cultured }\end{array}$ & Positive \\
\hline $\begin{array}{l}\text { Before } \\
\text { treatment }\end{array}$ & $\begin{array}{l}-4 \\
-3 \\
-2 \\
-1\end{array}$ & $\begin{array}{l}10 \\
15 \\
14 \\
20\end{array}$ & $\begin{array}{r}\% \\
90 \\
100 \\
86 \\
95\end{array}$ & $\begin{array}{l}3 \\
2 \\
6 \\
7\end{array}$ & $\begin{array}{c}\% \\
100 \\
100 \\
100 \\
100\end{array}$ \\
\hline $\begin{array}{l}\text { During } \\
\text { treatment }\end{array}$ & $\begin{array}{r}1 \\
2 \\
3 \\
4 \\
5 \\
6 \\
7 \\
8 \\
9 \\
10\end{array}$ & $\begin{array}{r}13 \\
6 \\
15 \\
16 \\
15 \\
17 \\
17 \\
13 \\
8 \\
12\end{array}$ & $\begin{array}{r}94 \\
16 \\
27 \\
6 \\
20 \\
12 \\
6 \\
8 \\
12 \\
0\end{array}$ & $\begin{array}{l}4 \\
4 \\
5 \\
4 \\
3 \\
7 \\
3 \\
4 \\
3 \\
4\end{array}$ & $\begin{array}{r}100 \\
100 \\
100 \\
100 \\
100 \\
100 \\
100 \\
100 \\
67 \\
100\end{array}$ \\
\hline $\begin{array}{l}\text { After } \\
\text { treatment }\end{array}$ & $\begin{array}{r}+1 \\
+2 \\
+3 \\
+4 \\
+5 \\
+6 \\
+7 \\
+8 \\
+9 \\
+10 \\
+30\end{array}$ & $\begin{array}{r}12 \\
9 \\
14 \\
13 \\
8 \\
10 \\
10 \\
8 \\
8 \\
12 \\
13\end{array}$ & $\begin{array}{r}0 \\
11 \\
21 \\
15 \\
25 \\
30 \\
11 \\
25 \\
38 \\
25 \\
46\end{array}$ & $\begin{array}{l}3 \\
4 \\
5 \\
4 \\
1 \\
2 \\
3 \\
2 \\
1 \\
3 \\
2\end{array}$ & $\begin{array}{l}100 \\
100 \\
100 \\
100 \\
100 \\
100 \\
100 \\
100 \\
100 \\
100 \\
100\end{array}$ \\
\hline
\end{tabular}

no change occurred in the carrier rates of patients treated with placebo ointment.

Eight of the 22 treated patients remained noncarriers for the duration of the study. Six of these 8 patients were followed for more than 30 days after therapy and the remaining 2 patients were followed for 13 and 21 days after therapy.

Staphylococci isolated from 7 of the 14 patients who became carriers after treatment were different phage types than the ones isolated from the patients before therapy, and 7 were the same phage type as that isolated before therapy. Therefore, a change in carrier status-either conversion of carriers to noncarriers or change in type of staphylococcus carried-occurred in 15 of 22 patients (68 per cent). No change in phage types occurred in patients treated with ointment without methicillin.

The time required before cultures became positive after therapy varied from 3 to 58 days, with a median value of 13 days, and no differences were seen in the time of reappearance of staphylococci in patients who acquired the same phage type as

TABLE III

Effect of topical methicillin on number of staphylococci in positive cultures

\begin{tabular}{|c|c|c|c|}
\hline & & \multicolumn{2}{|c|}{$\begin{array}{l}\text { Mean of log of } \\
\text { positive cultures }\end{array}$} \\
\hline \multicolumn{2}{|c|}{ Treatment day } & $\begin{array}{c}\text { Treated } \\
\text { patients } \\
\text { (14 cases) }\end{array}$ & $\begin{array}{l}\text { Placebo } \\
\text { patients } \\
(7 \text { cases) }\end{array}$ \\
\hline $\begin{array}{l}\text { Before } \\
\text { treatment }\end{array}$ & $\begin{array}{l}-4 \\
-3 \\
-2 \\
-1\end{array}$ & $\begin{array}{l}4.8 \\
5.6 \\
4.6 \\
4.3\end{array}$ & $\begin{array}{l}4.4 \\
3.9 \\
5.1 \\
5.4\end{array}$ \\
\hline $\begin{array}{l}\text { During } \\
\text { treatment }\end{array}$ & $\begin{array}{r}1 \\
2 \\
3 \\
4 \\
5 \\
6 \\
7 \\
8 \\
9 \\
10\end{array}$ & $\begin{array}{l}3.3 \\
\\
2.2 \\
1.5 \\
2.4 \\
3.1 \\
1.3 \\
2.3 \\
2.6\end{array}$ & $\begin{array}{l}5.2 \\
4.8 \\
5.3 \\
4.8 \\
5.5 \\
5.1 \\
4.2 \\
5.1 \\
5.1 \\
5.3\end{array}$ \\
\hline $\begin{array}{l}\text { After } \\
\text { treatment }\end{array}$ & $\begin{array}{r}+1 \\
+2 \\
+3 \\
+4 \\
+5 \\
+6 \\
+7 \\
+8 \\
+9 \\
+10 \\
+30\end{array}$ & $\begin{array}{l}1.5 \\
3.2 \\
2.6 \\
4.2 \\
2.1 \\
2.9 \\
3.2 \\
3.8 \\
5.2 \\
4.6\end{array}$ & $\begin{array}{l}4.0 \\
4.5 \\
5.1 \\
4.8 \\
5.5 \\
4.1 \\
4.2 \\
4.3 \\
5.1 \\
4.3 \\
5.0\end{array}$ \\
\hline
\end{tabular}


TABLE IV

Antimicrobial resistance of staphylococci isolated before and after treatment *

\begin{tabular}{|c|c|c|c|c|}
\hline & \multicolumn{2}{|c|}{ Before treatment } & \multicolumn{2}{|c|}{ After treatment } \\
\hline & $\begin{array}{l}\text { No. of } \\
\text { patients }\end{array}$ & Patients & $\begin{array}{l}\text { No. of } \\
\text { patients }\end{array}$ & Patients \\
\hline \multirow[t]{2}{*}{$\begin{array}{l}\text { Noncarriers } \\
\text { Sensitive } \\
\text { Pen. resistant } \\
\text { Pen., Tetra. resistant } \\
\text { Pen., Tetra., Eryth. resistant } \\
\text { Pen., Tetra., Eryth., Chloro. resistant }\end{array}$} & $\begin{array}{r}0 \\
10 \\
4 \\
2 \\
3 \\
3\end{array}$ & $\left.\begin{array}{c}\% \\
0 \\
45 \\
18 \\
9 \\
14 \\
14\end{array}\right\} 37$ & $\begin{array}{l}8 \\
5 \\
6 \\
1 \\
1 \\
1\end{array}$ & $\left.\begin{array}{l}\% \\
36 \\
23 \\
27 \\
5 \\
5 \\
5\end{array}\right\} 15$ \\
\hline & 22 & 100 & 22 & 100 \\
\hline
\end{tabular}

*Pen. = penicillin, Tetra. $=$ tetracycline, Eryth. $=$ erythromycin, Chloro. $=$ chloroamphenicol.

compared with patients from whom phage types different from those present before therapy were isolated.

Pretreatment cultures from patients who became nasal carriers after treatment contained larger numbers of staphylococci than pretreatment cultures from patients who remained noncarriers after treatment (Table I). There was no difference in the number of staphylococci isolated from pretreatment cultures of patients from whom the same phage type of staphylococci was isolated as compared with patients from whom a new phage type of staphylococci was isolated.

Topical administration of methicillin caused a rapid drop in carrier rates and in the number of staphylococci isolated from those who remained carriers (Tables II and III). After therapy, the mean carrier rate gradually increased until 46 per cent of the cultures obtained 30 days or longer after treatment contained coagulase-positive staphylococci. In patients who became carriers

TABLE V

Phage patterns of staphylococci isolated before and after treatment

\begin{tabular}{lccccc}
\hline \hline & \multicolumn{2}{c}{$\begin{array}{c}\text { Before } \\
\text { treatment }\end{array}$} & & \multicolumn{2}{c}{$\begin{array}{c}\text { After } \\
\text { treatment }\end{array}$} \\
\cline { 2 - 3 } \cline { 5 - 6 } & $\begin{array}{c}\text { No. of } \\
\text { patients }\end{array}$ & Patients & $\begin{array}{c}\text { No. of } \\
\text { patients }\end{array}$ & Patients \\
\hline Noncarriers & 0 & $\%$ & & $\%$ \\
Not typeable & 5 & 23 & & 7 & 36 \\
Group I & 1 & 5 & & 0 & 32 \\
Group II & 4 & 18 & & 0 \\
Group III & 2 & 9 & & 2 & 9 \\
Type 80/81 & 10 & 45 & & 3 & 14 \\
& 22 & 100 & 22 & 100 \\
\hline
\end{tabular}

again, the number of staphylococci isolated from positive cultures did not equal pretreatment levels or the number isolated from patients treated with placebo ointment until 10 days after discontinuation of treatment.

Comparisons of staphylococci isolated before and after treatment showed that 37 per cent of the patients before therapy and 15 per cent of the patients after therapy were carriers of multiple-drugresistant strains (Table IV). Forty-five per cent of the patients were carriers of a phage type $80 / 81$ staphylococcus before treatment, but only 14 per cent were carriers of this staphylococcus after treatment (Table V).

A large proportion of air samples and skin cultures collected from treated patients before therapy contained coagulase-positive staphylococci (Table VI). During treatment the number of samples containing coagulase-positive staphylococci was very low. After therapy, staphylococci were isolated infrequently from patients who were not nasal carriers at the time skin cultures and air samples were collected, but were isolated as frequently from patients who had reacquired

TABLE VI

Frequency of positive air samples and skin cultures for staphylococci before, during, and after topical treatment with methicillin

\begin{tabular}{|c|c|c|c|}
\hline & \multicolumn{2}{|c|}{ Air samples } & \multirow{2}{*}{$\begin{array}{c}\text { Skin } \\
\text { cultures }\end{array}$} \\
\hline & Active & Inactive & \\
\hline $\begin{array}{l}\text { Before treatment } \\
\text { During treatment } \\
\text { After treatment (noncarrier) } \\
\text { After treatment (nasal carrier) }\end{array}$ & $\begin{array}{l}7 / 13^{*} \\
3 / 10 \\
3 / 23 \\
6 / 10\end{array}$ & $\begin{array}{l}4 / 15 \\
0 / 10 \\
2 / 23 \\
2 / 10\end{array}$ & $\begin{array}{l}5 / 15 \\
0 / 10 \\
0 / 25 \\
6 / 13\end{array}$ \\
\hline
\end{tabular}

* No. positive/no. samples. 
TABLE VII

Correlation of frequency of positive skin cultures to number of nasal staphylococci

\begin{tabular}{cccc}
\hline \hline Nasal count & $\begin{array}{c}\text { No. of } \\
\text { cultures }\end{array}$ & $\begin{array}{c}\text { No. } \\
\text { positive }\end{array}$ & Positive \\
\hline 0 & 40 & 0 & $\%$ \\
$10^{1}$ to $10^{4}$ & 12 & 3 & 25 \\
$>10^{4}$ & 30 & 11 & 37 \\
& 82 & 14 & 17 \\
\hline
\end{tabular}

staphylococci as from patients before treatment. No changes occurred in the frequency of positive cultures or in the number of staphylococci isolated in air samples or from skin cultures of patients treated with placebo ointment.

The frequency of positive skin cultures was greater in patients who were carriers of more than 10,000 staphylococci per nasal swab than in carriers of less than 10,000 (Table VII). In patients in whom nasal staphylococci had been eliminated by nasal ointment, no staphylococci were isolated from the skin.

No correlation was found between the frequency of positive air samples and the number of staphylococci isolated from nasal carriers when the air samples were collected while the patient rested quietly in bed (Table VIII). However, in patients in whom nasal staphylococci had been eliminated, a very low proportion of air samples contained staphylococci.

When the patients' bedding was shaken lightly for 15 seconds of the 1.5-minute collection period, positive air samples were more frequent around carriers of more than 10,000 staphylococci than around either carriers of less than 10,000 staphylococci or around noncarriers (Table IX). In addition, more than 5 staphylococcal colonies were present in 32 per cent of air samples around nasal

TABLE VIII

Correlation of frequency of positive air samples from patients atirest to number of nasal staphylococci

\begin{tabular}{cccc}
\hline \hline Nasal count & $\begin{array}{c}\text { No. of } \\
\text { samples }\end{array}$ & $\begin{array}{c}\text { No. } \\
\text { positive }\end{array}$ & Positive \\
\hline 0 & 36 & 1 & $\%$ \\
$10^{1}$ to $10^{4}$ & 16 & 4 & 25 \\
$>10^{4}$ & 27 & 6 & 22 \\
& 79 & 11 & 14 \\
\hline
\end{tabular}

TABLE IX

Correlation of frequency of positive air samples from patients during activity with number of nasal staphylococci

\begin{tabular}{|c|c|c|c|c|c|}
\hline Nasal count & $\begin{array}{c}\text { Air } \\
\text { samples }\end{array}$ & $\begin{array}{c}\text { No. } \\
\text { positive }\end{array}$ & Positive & & ines/ \\
\hline $\begin{array}{c}0 \\
10^{1} \text { to } 10^{4} \\
>10^{4}\end{array}$ & $\begin{array}{l}37 \\
13 \\
28\end{array}$ & $\begin{array}{r}5 \\
5 \\
17\end{array}$ & $\begin{array}{l}\% \\
14 \\
37 \\
61\end{array}$ & $\begin{array}{c}\text { no. } \\
1 \\
2 \\
9\end{array}$ & $\begin{array}{r}\% \\
3 \\
15 \\
32\end{array}$ \\
\hline
\end{tabular}

carriers of more than 10,000 colonies, in 15 per cent of air samples of carriers of less than 10,000 colonies, and in only 3 per cent of air samples around patients in whom nasal staphylococci had been completely suppressed.

Eighty-one per cent of staphylococci isolated from air samples or from the skin of nasal carriers were the same phage types and were susceptible to the same antibiotics as the staphylococci isolated from the nose at the same time. All staphylococci isolated from air samples around noncarriers were of different phage types and had different antimicrobial susceptibilities than the staphylococci isolated either from pretreatment nasal cultures or from nasal cultures obtained at a later period in those patients who reacquired nasal staphylococci. No local or generalized reactions to topical methicillin were observed during or after treatment.

\section{DISCUSSION}

In general hospitals where antibiotics are used extensively, there is a large reservoir of staphylococci resistant to penicillin $\mathrm{G}$, tetracycline, erythromycin and chloramphenicol. Administration of these antibiotics to patients or personnel often eliminates sensitive staphylococci present in the nose before therapy, but treated patients acquire new strains from the hospital environment during therapy which are resistant to the administered drug and to several other antibiotics also $(3,4)$.

Methicillin is highly resistant to staphylococcal penicillinase and, in this hospital, no coagulasepositive staphylococci of over 3,000 strains tested were resistant to methicillin. In a previous study (2), systemic therapy with methicillin rapidly eliminated nasal staphylococci from patients without staphylococcal infections at other sites. Since there were no strains resistant to methicillin, treated patients did not acquire new strains from the hospital environment during treatment. 
As shown in this study, nasal treatment with methicillin also rapidly depressed both the number of nasal carriers and the number of staphylococci present in those patients who remained carriers. Associated with the reduction in nasal staphylococci was a marked reduction in the frequency with which staphylococci could be isolated from a standard area of patients' skin and a reduction in the frequency with which staphylococci could be recovered from the air around treated patients.

In patients who became nasal carriers after treatment was discontinued, a large proportion of both skin cultures and air samples again contained coagulase-positive staphylococci. However, the strains acquired after therapy were less frequently multiple-drug-resistant or lysed by phages $80 / 81$ than those isolated before therapy.

In this study, patients were selected who would remain in the hospital at least 3 weeks. Because of the nature of their illnesses, many had received antibiotics during previous hospitalizations and the proportion of staphylococci lysed by phages $80 / 81$ and resistant to several antibiotics was higher than usually found in newly admitted, untreated patients (3).

If fewer strains before treatment had been drugresistant, an increase in the number of such strains after completion of treatment might have occurred in proportion to availability of drug-resistant strains in the environment. However, selection of drug-resistant strains during treatment would require strains resistant to methicillin. Gezon, Rogers, Thompson and Hatch (13) have reported that more than one phage type of staphylococcus can be isolated from a large proportion of nasal carriers. It is possible that new phage types isolated after therapy with methicillin were present before treatment and do not represent true acquisition of new phage types. However, the close correlation between phage types of staphylococci isolated from the nose, skin, and air around individual carriers both before and after treatment suggests that changes in the predominant type of nasal staphylococci did occur.

At the present time, methicillin differs from most antimicrobial agents in suppressing nasal staphylococci, skin staphylococci, and aerial dissemination of these bacteria and in reducing the proportion of multiple-drug-resistant strains from these sources. No strains resistant to methicillin have been detected in our hospital; should resistant strains appear in large numbers, then patients treated with methicillin would be expected to acquire methicillin-resistant staphylococci from the hospital environment in a manner similar to the acquisition of strains resistant to penicillin G, tetracycline, and erythromycin by patients during treatment with these drugs. A few strains resistant to methicillin have been reported from England (14), but it is too early to predict accurately how virulent or transmissible these staphylococci will be or how frequently they may be encountered after methicillin has been used for a longer period of time.

The relative role of nasal carriers of staphylococci in initiating staphylococcal infections has not been completely established. However, a number of epidemics of staphylococcal diseases has been ascribed to a simple nasal carrier (1517). Also, in two studies $(18,19)$ patients who were nasal carriers had a higher incidence of postoperative staphylococcal infections than patients who were noncarriers, and the increased incidence of infection was due to staphylococci of the same phage types as those present in the nose before the infection occurred.

It has rarely been possible to prove that infections were caused by aerial dissemination or by direct contact with skin staphylococci. However, studies by Wolinsky, Lipsitz, Mortimer and Rammelkamp (20) have shown that, at least in one nursery, direct contact by hands was very important in dissemination of staphylococci. Regardless of the method of transfer, the present studies suggest that a decrease in the number of nasal staphylococci or elimination of the nasal carrier status should reduce both the risk of aerial dissemination and of infections from skin staphylococci.

This study was designed to test the correlation between nasal staphylococci and dissemination of these organisms onto the skin and into the air. Until the role of nasal carriers in initiating staphylococcal infections can be established and until the risks of selecting methicillin-resistant staphylococci with either topical or systemic therapy are known, topical treatment of nasal carriers with methicillin as a means of reducing staphylococcal infections must remain an experimental approach. 


\section{SUM MARY}

Nasal administration of methicillin rapidly decreased both the number of nasal carriers of staphylococci and the number of staphylococci isolated from patients who remained carriers.

Approximately one-third of treated patients reacquired staphylococci of the same phage types as those present before therapy; in one-third of the patients different phage types of staphylococci were isolated after treatment; and one-third remained noncarriers.

Staphylococci isolated after treatment were less frequently multiple-drug-resistant than those isolated before treatment.

Depression of nasal staphylococci was followed by a rapid reduction of skin staphylococci and of aerial dissemination of these organisms.

\section{REFERENCES}

1. White, A. Relation between quantitative nasal cultures and dissemination of staphylococci. J. Lab. clin. Med. 1961, 58, 273.

2. White, A., and Varga, D. T. Antistaphylococcal activity of dimethoxyphenyl penicillin in A Symposium on the New Dimethoxyphenyl Penicillin, Paul A. Bunn, Ed. Syracuse, N. Y., 1961, p. 146.

3. White, A. Quantitative studies of nasal carriers of staphylococci among hospitalized patients. J. clin. Invest. 1961, 40, 23.

4. Knight, V., and Holzer, A. R. Studies on staphylococci from hospital patients. I. Predominance of strains of Group III phage patterns which are resistant to multiple antibiotics. J. clin. Invest. 1954, 33, 1190.

5. Martin, W. J., Nichols, D. R., and Henderson, E. D. The problem of management of nasal carriers of staphylococci. Proc. Mayo Clin. 1960, 35, 282.

6. Berntsen, C. A., and McDermott, W. Increased transmissibility of staphylococci to patients receiving an antimicrobial drug. New Engl. J. Med. 1960, 262, 637.

7. Rifkind, D., and Knight, V. Treatment of staphylococcal and streptococcal infections with dimethoxyphenyl penicillin in A Symposium on the New Dimethoxyphenyl Penicillin, Paul A. Bunn, Ed. Syracuse, N. Y., 1961, p. 160.
8. Stewart, G. T. Microbiological studies on sodium $6-(2,6$ dimethoxybenzamido) penicillinate monohydrate (BRL 1241) in vitro and in patients. Brit. med. J. 1960, 2, 694.

9. Stewart, G. T., Nixon, H. H., Coles, H. M. T., Kesson, C. W., Lawson, D., Thomas, R. G., Mishra, J. N., Mitchell, M. E., Semmens, J. M., and Wade, T. H. H. Report on the clinical use of BRL 1241 in children with staphylococcal and streptococcal infections. Brit. med. J. 1960, 2, 703.

10. White, A., Hemmerly, T., Martin, M. P., and Knight, V. Studies of the origin of drug-resistant staphylococci in a mental hospital. Amer. J. Med. 1959, 27, 26.

11. Wolf, H. W., Skaliy, P., Hall, L. B., Harris, M. M., Decker, H. M., Buchanan, L. M., and Dahlgren, C. M. Sampling microbiological aerosols. Public Health Monograph no. 60, U.S. Public Health Service, 1959.

12. Jackson, G. G., and Finland, M. Comparison of methods for determining sensitivity of bacteria to antibiotics in vitro. A. M. A. Arch. intern. Med. 1951, 88, 446.

13. Gezon, H. M., Rogers, K. D., Thompson, D. J., and Hatch, T. F. Environmental aspects of staphylococcal infections acquired in hospitals. II. Some controversial aspects in the epidemiology of hospital nursery staphylococcal infections. Amer. J. pub. Hith 1960, 50, 473.

14. Jevons, M. P. (Celbenin) Resistant staphylococci. Brit. med. J. 1961, 1, 124.

15. Penikett, E. J. K., Knox, R., and Liddell, J. An outbreak of post-operative sepsis. Brit. med. J. 1958, 1, 812.

16. Shooter, R. A., Griffiths, J. D., Cook, J., and Williams, R. E. O. Outbreak of staphylococcal infection in a surgical ward. Brit. med. J. 1957, 1, 433.

17. Blowers, R., Mason, G. A., Wallace, K. R., and Walton, M. Control of wound infections in a thoracic surgery unit. Lancet 1955, 2, 786.

18. Williams, R. E. O., Jevons, M. P., Shooter, R. A., Hunter, C. J. W., Girling, J. A., Griffiths, J. D., and Taylor, G. W. Nasal staphylococci and sepsis in hospital patients. Brit. med. J. 1959, 2, 658.

19. Weinstein, H. J. The relation between nasal-staphylococcal-carrier state and the incidence of postoperative complications. New Engl. J. Med. 1959, 260, 1303.

20. Wolinsky, E., Lipsitz, P. J., Mortimer, E. A., Jr., and Rammelkamp, C. H., Jr. Acquisition of staphylococci by newborns. Direct versus indirect transmission. Lancet 1960, 2, 620. 